\title{
ANALISIS TRIWULANAN: \\ Perkembangan Moneter, Perbankan dan Sistem Pembayaran, Triwulan IV - 2011
}

\author{
Tim Penulis Laporan Triwulanan, Bank Indonesia
}

Pertumbuhan ekonomi Indonesia pada triwulan I - 2012 tumbuh sebesar 6,3\% (yoy). Sumber utama pertumbuhan ekonomi berasal dari konsumsi rumah tangga yang masih kuat sejalan dengan optimisme konsumen yang tetap tinggi dan investasi (PMTB) yang didukung oleh iklim usaha yang kondusif dan potensi pendanaan yang meningkat. Sementara itu, kinerja ekspor tumbuh melambat akibat berlanjutnya pelemahan ekonomi global yang menyebabkan turunnya daya serap negara mitra dagang utama. Di tengah perlambatan kinerja ekspor, impor masih tumbuh tinggi dengan masih kuatnya permintaan domestik. Ke depan, prospek ekonomi Indonesia keseluruhan 2012 masih tetap kuat pada kisaran 6,3 - 6,7\%, meskipun berbagai faktor risiko masih tetap perlu diwaspadai.

Kinerja Neraca Pembayaran Indonesia (NPI) selama triwulan I - 2012 menunjukkan perbaikan dengan mencatat defisit yang lebih kecil dibandingkan dengan kinerja pada triwulan IV 2011. Perbaikan tersebut ditopang oleh transaksi modal dan keuangan yang kembali mengalami surplus sehingga mampu menutupi sebagian dari defisit transaksi berjalan yang membesar. Dengan perkembangan tersebut, jumlah cadangan devisa pada akhir Maret 2012 menjadi USD110,5 miliar atau setara dengan 6,2 bulan impor dan pembayaran utang luar negeri pemerintah.

Nilai tukar rupiah yang mengalami pelemahan selama triwulan I-2012. Rupiah secara point-to-point melemah sebesar 0,87\% (qtq) ke level Rp 9.139/USD atau secara rata-rata melemah 1,03\% (qtq) menjadi Rp 9.066/USD. Kendati melemah, volatilitas nilai tukar rupiah masih terjaga pada level yang rendah dibandingkan dengan negara-negara di kawasan. Kondisi tersebut tidak terlepas dari langkah stabilisasi nilai tukar rupiah yang ditempuh Bank Indonesia, baik dengan intervensi di pasar valas maupun pembelian Surat Berharga Negara (SBN) dari pasar sekunder, yang pada gilirannya tetap menjaga stabilitas pergerakan nilai tukar rupiah. Berdasarkan faktor yang memengaruhinya, tekanan terhadap nilai tukar rupiah antara lain berasal dari penyesuaian portofolio investor asing akibat pengaruh sentimen global dan ekspektasi inflasi yang meningkat di dalam negeri. Selain itu, permintaan valas yang cenderung meningkat seiring dengan kuatnya impor, termasuk impor migas untuk konsumsi BBM di dalam negeri, juga menimbulkan tekanan terhadap nilai tukar rupiah. 
Inflasi IHK selama triwulan I-2012 tetap terkendali. Inflasi IHK pada triwulan I - 2012 masih tercatat rendah sebesar 0,88\% (qtq) atau 3,97\% (yoy), meskipun sedikit meningkat dibandingkan dengan triwulan sebelumnya. Berdasarkan komponennya, sumber tekanan inflasi terutama berasal dari inflasi kelompok volatile food, sementara itu, inflasi kelompok inti dan administered price masih tercatat rendah. Tekanan inflasi dari kelompok volatile food disebabkan oleh masih tingginya harga beras dan adanya kenaikan harga komoditas bumbu-bumbuan. Inflasi inti yang masih tercatat rendah dipengaruhi oleh terjaganya pasokan barang dan jasa, meskipun kenaikan harga komoditas global non-pangan serta depresiasi rupiah sedikit memberikan tekanan kenaikan. Sementara itu, inflasi administered price tetap rendah kendati Pemerintah pada triwulan laporan menaikkan harga cukai rokok. Dengan perkembangan inflasi IHK hingga triwulan I - 2012 tersebut, Bank Indonesia memperkirakan inflasi masih konsisten dengan sasaran sebesar 4,5\% $\pm 1 \%$ pada 2012 dan 2013. Namun demikian, risiko inflasi yang berasal dari peningkatan ekspektasi inflasi yang dipicu oleh ketidakpastian rencana penyesuaian subsidi Bahan Bakar Minyak (BBM) akan tetap dicermati.

Sejalan dengan kinerja makroekonomi yang tetap terjaga, stabilitas sistem keuangan juga tetap terkendali. Stabilitas sistem keuangan tersebut didukung oleh kinerja sektor perbankan yang tetap terjaga sebagai industri yang mendominasi sistem keuangan Indonesia. Rasio kecukupan modal (CAR/Capital Adequacy Ratio), tercatat tinggi mencapai 18,41\% pada Februari 2012, jauh di atas CAR minimum 8\%. Permodalan bank yang tinggi tersebut dicapai melalui peningkatan profitabilitas bank. Sementara itu, intermediasi perbankan juga terus membaik tercermin dari pertumbuhan kredit yang hingga akhir Februari 2012 mencapai 24,2\% (yoy). Penyaluran kredit perbankan tersebut lebih ditujukan pada sektor-sektor produktif sebagaimana tampak dari Kredit Investasi yang tumbuh tinggi (33,2\% yoy), sedangkan Kredit Modal Kerja dan Kredit Konsumsi masing-masing tumbuh sebesar 23,4\% (yoy) dan 19,6\% (yoy).

Kinerja perekonomian Indonesia juga didukung oleh keandalan sistem pembayaran dan terpenuhinya kebutuhan uang kartal masyarakat. Sistem pembayaran sebagai bagian dari sistem keuangan tetap menunjukkan kinerja yang terjaga selama triwulan I - 2012. Nilai dan volume transaksi sistem pembayaran selama triwulan I - 2012 menunjukkan peningkatan sejalan dengan naiknya kegiatan perekonomian. Meningkatnya transaksi sistem pembayaran tersebut didukung dengan ketersediaan Sistem Bank Indonesia - Real Time Gross Settlement (BI-RTGS), Bank Indonesia - Scripless Securities Settlement System (BI - SSSS) dan Sistem Kliring Bank Indonesia (SKNBI), yang mencapai 99,97\%. Selain itu, kinerja sistem pemrosesan Alat Pembayaran Menggunakan Kartu (APMK) dan Uang Elektronik yang diselenggarakan oleh pihak di luar Bank Indonesia juga tetap terjaga. Dari sisi pengedaran uang, kebutuhan uang kartal masyarakat masih cukup tinggi. Tingginya kebutuhan uang kartal masyarakat diikuti dengan adanya peningkatan Uang yang Diedarkan (UYD) selama triwulan I - 2012. 